University of Nebraska - Lincoln

DigitalCommons@University of Nebraska - Lincoln

USDA National Wildlife Research Center - Staff Publications
U.S. Department of Agriculture: Animal and Plant Health Inspection Service

April 2003

\title{
Impacts of small mammals and birds on low-tillage, dryland crops
}

\author{
Ray T. Sterner \\ USDA-APHIS-Wildlife Services \\ Brett E. Petersen \\ USDA-APHIS-Wildlife Services \\ Stanley E. Gaddis \\ USDA-APHIS-Wildlife Services \\ Kenneth L. Tope \\ USDA-APHIS-Wildlife Services \\ David J. Poss \\ Colorado State University, Fort Collins, Department of Bioagricultural Sciences and Pest Management
}

Follow this and additional works at: https://digitalcommons.unl.edu/icwdm_usdanwrc

Part of the Environmental Sciences Commons

Sterner, Ray T.; Petersen, Brett E.; Gaddis, Stanley E.; Tope, Kenneth L.; and Poss, David J., "Impacts of small mammals and birds on low-tillage, dryland crops" (2003). USDA National Wildlife Research Center Staff Publications. 276.

https://digitalcommons.unl.edu/icwdm_usdanwrc/276

This Article is brought to you for free and open access by the U.S. Department of Agriculture: Animal and Plant Health Inspection Service at DigitalCommons@University of Nebraska - Lincoln. It has been accepted for inclusion in USDA National Wildlife Research Center - Staff Publications by an authorized administrator of DigitalCommons@University of Nebraska - Lincoln. 


\title{
Impacts of small mammals and birds on low-tillage, dryland crops
}

\author{
Ray T. Sterner ${ }^{\mathrm{a}, *}$, Brett E. Petersen ${ }^{\mathrm{a}}$, Stanley E. Gaddis ${ }^{\mathrm{a}}$, Kenneth L. Tope ${ }^{\mathrm{a}}$, David J. Poss ${ }^{\mathrm{b}}$ \\ ${ }^{\mathrm{a}}$ USDA, APHIS, WS, National Wildlife Research Center, 4101 LaPorte Avenue, Fort Collins, CO 80521-2154, USA \\ ${ }^{\mathrm{b}}$ Department of Bioagricultural Sciences and Pest Management, Colorado State University, Fort Collins, CO 80523-1177, USA
}

Received 23 August 2002; received in revised form 28 October 2002; accepted 1 November 2002

\begin{abstract}
During 2000-2001, small mammals, birds, and potential corn/soybean damage were studied at a low-tillage, non-irrigated agricultural research site in the Colorado Piedmont. A small mammal survey involved four trapping sessions and 18, 12-live-trap grids each. Within years, two grids each were placed at random, fixed locations in experimental corn, fallow, millet, pea, soybean, sunflower, and wheat plots at the site; two off-plot grids each were set at random, fixed locations $<100 \mathrm{~m}$ from the north and south edge of these plots. In 2001, periodic bird observations were conducted, and damage to corn and soybean plants was assessed. Capture rates were low during all trap sessions (range $0.1 \%-3.3 \%, \bar{X}=2.2 \%$ ). Sixty-three small mammals were captured and 39 were recaptured. Captures included deer mouse (Peromyscus maniculatus), northern grasshopper mouse (Onychomys leucogaster), thirteen-lined ground squirrel (Spermophilus tridecemlineatus), and western harvest mouse (Reithrodontomys megalotis). Deer mice accounted for 56 of the initial captures $(88.9 \%)$. In-crop captures $(n=15)$ and recaptures $(n=16)$ were most frequent in wheat plots. Bird counts were low and included horned lark (Eremophila alpestris), killdeer plover (Charadrius vociferus), lark bunting (Calamospiza melanocorys), mountain plover (Charadrius montanus), mourning dove (Zenaida macroura), and western meadowlark (Sturnella neglecta). No direct seed removal, sprout removal, or plant clipping by small mammals or birds was observed, but some clipping of soybean plants was attributed to deer (Odocoileus virginianus and O. hemionus) and jack rabbits (Lepus townsendii or L. californicus). Plant debris accumulation is viewed as a key factor determining small mammal abundance and potential damage in low-till agriculture.

Published by Elsevier Science Ltd.
\end{abstract}

Keywords: Bird; Deer mouse; Dryland; Corn; Crop damage; Great Plains; Low-tillage; Plant debris; Small mammal; Soybean

\section{Introduction}

The Great Plains of the US have been cultivated extensively for over a century. During this time, experimental stations have documented $\approx 60 \%$ and $\approx 24 \%$ declines of soil carbon and nitrogen, respectively (Bauer and Black, 1981; Bowman et al., 1990). Low-tillage agriculture, coupled with prescribed crop rotation and fallow schemes, has received increased study as a potential way of reducing soil erosion and soil-moisture loss, but of increasing soil-moisture storage via increased soil carbon and nitrogen retention (Dhuyvetter et al., 1996; Krall and Schuman, 1996; Peterson et al., 1996, 2000).

Low-tillage, dryland agriculture presents new issues for wildlife damage management in The Great Plains. The potential for vertebrate pests to damage these crops is

*Corresponding author. Tel.: + 1-970-266-6170; fax: + 1-970-2666157.

E-mail address: ray.t.sterner@aphis.usda.gov (R.T. Sterner). substantial. The lack of plowing could allow establishment of long-term rodent burrow systems, and the build up of soil-surface debris could create enhanced habitats for small mammals (e.g., mice, ground squirrels and voles). Few studies have delineated vertebrate damage in low-tillage situations, especially those involving dryland practices (e.g., Hines, 1993, 1997; Hyngstrom et al., 1996).

This research sought to document small mammal densities and diversity, bird foraging activity, and potential damage of soybean and corn crops at a low-tillage, dryland site in the Colorado Piedmont (see Peterson et al., 2000).

\section{Methods and materials}

\subsection{Site}

The site consisted of $48(27.45 \times 125.00 \mathrm{~m})$ plots aligned as an east-west strip (1318-m) near Briggsdale, Colorado (Fig. 1). The site has been used for dryland 
research since the Spring of 1999 (Peterson et al., 2000). Plots were planted in six crops (i.e., Asgrow 3901 soybean, Austrian winter pea/Longhorn wheat (mix), Lamar/Prowers wheat, Pioneer 3752 corn, Triumph $765 \mathrm{C}$ sunflower, and Foxtail millet) plus fallow. Crops were varied systematically among plots to assess potential yearly "rotation" effects upon diverse soil nutrient, soil-moisture, and crop yield variables associated with low-tillage, non-irrigated agriculture (Peterson et al., 2000; Poss, 2001).

The site is located in Colorado's Piedmont, an approximately $72,500 \mathrm{~km}^{2}$ northeastern and east-central area of the state. Geographers distinguish this westernmost feature of The Great Plains from both the High Prairie of humid and less-elevated terrain along the easternmost border with Kansas and from the Raton Section of mesas and hill country along the southeastern border with New Mexico (Hammerson, 1999). It is an area of low precipitation $(30-45 \mathrm{~cm}$ annually), low humidity (10-25\% RH daily), and sporadic high winds ( $>60 \mathrm{~km} / \mathrm{h}$ ) or tornadoes. Elevation varies from $\approx 1000$ to $\approx 2000 \mathrm{~m}$ (generally east to west) and, if uncultivated, consists mainly of grassland ecosystems (Fitzgerald et al., 1994).

\subsection{Small mammal surveys}

Small mammals were caught using Sherman live traps $(7.7 \times 7.7 \times 25.5 \mathrm{~cm})$. Eighteen, 12-trap grids $(2 \times 6$ grid; $10-\mathrm{m}$ trap spacing; 216 traps/night) were set up at randomly designated locations annually; two grids each were placed in randomly assigned corn, fallow, millet, pea/wheat, soybean, sunflower, and wheat plots (i.e., 14 grids) and four grids were placed adjacent to the experimental plots $(2$ each $<100 \mathrm{~m}$ north and south of the site). A plastic cattle ear tag was inserted into the ground using a large nail to mark the northwest corner

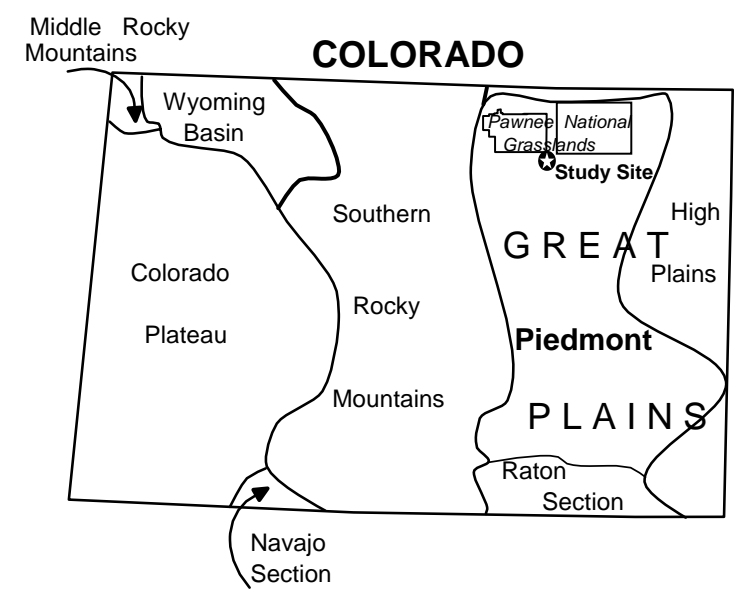

Fig. 1. The physiographic regions of Colorado and the approximate location of the study site (after Hammerson, 1999). of each trap grid for ease of plot identification and trap placement.

Trapping sessions occurred during July $10-13$ and September 11-14, 2000 and April 30-May 1 and July 10-13, 2001. The April-May session was half as long as the other sessions because snowfall prevented further trapping. "Inoperable" or "closed-without-capture" trap sets (e.g., closed by wind, missed capture, etc.) were uncounted, yielding 798, 834, 405 and 759 "operable" sets during the respective sessions.

Traps were opened daily within $2.5 \mathrm{~h}$ of sunset and checked and closed as soon as possible the next morning $(<3.0 \mathrm{~h}$ after sunrise). All traps were closed during daytime hours. Each trap was baited with a small amount of a peanut-butter and rolled-oats mixture. A Purina Rodent Biscuit (Purina Inc., St. Louis, MO) and a small ball of poly fil was inserted into each trap to reduce hypothermia in captured animals. Traps that captured an animal were replaced with a clean trap for subsequent trapping.

Upon capture, each animal was examined to identify species, gender, age (i.e., adult, sub-adult, juvenile), reproductive status, and overall health. Each animal was then weighed, affixed with metal ear tags and released at the original trap location.

\subsection{Plant damage measurements}

Corn and soybean were planted in 76-cm row widths, with corn seeds inserted at $\approx 26.7-\mathrm{cm}$ spacings and soybean seeds planted densely within rows. Corn was planted on May 10, 2001, and soybean was planted on May 25, 2001. Ten, 0.93- $\mathrm{m}^{2}$-mesh-woven-wire exclosures $\left(152 \times 61 \times 30 \mathrm{~cm}^{3}\right.$ or $\left.152 \times 61 \times 15 \mathrm{~cm}^{3}\right)$ were centered over random portions of rows within two randomly assigned corn and soybean plots immediately after planting. Ten, $152-\mathrm{cm}$, randomly located segments of row were also marked with flags for "unprotected" (non-exclosure or control) measurements within these plots. In the corn plots, exclosures were in place for 14 consecutive days (three damage measurements); whereas, in soybean plots, exclosures were in place for 39 consecutive days (seven damage measurements). Exclosures were removed from all corn plants on May 23 and moved to the soybean plots on May 25.

Numbers of sprouts, numbers of clipped plants, and numbers of disturbed-soil digs were counted periodically by two researchers making successive, independent inspections $(<2 \mathrm{~min}$ apart) of each exclosure or nonexclosure segment. Sprouts were counted as individual plant stems. Clipped plants could involve any cut (bitten) foliage, but multiple damage points per sprout were not counted. Soil digs for protected row segments were scored along the outside perimeter of the wire exclosures; whereas, digs in unprotected row segments were scored within the $152-\mathrm{cm}$ segment and $\approx 38-\mathrm{cm}$ on 
either side of the plant row. Damage was measured on May 10, 15, 23; June 6, 13, 20, 27; July 11, 2001 in corn and May 25; June 1, 6, 13, 20, 27; and July 2, 2001 in soybeans. Correlations between the two researchers' measurements showed good agreement, varying between 0.75 and 0.99 .

\subsection{Bird observations}

Bird observations were performed in each of the four corn plots at the site for $0.5 \mathrm{~h}$ (between 0800 and $1200 \mathrm{~h}$ ) on 3 days (May 10, 15, and 23, 2001) and in the four soybean plots for $0.5 \mathrm{~h}(0800-1200 \mathrm{~h})$ on 2 days (i.e., May 25 and 31,2001). Observations were always made by the same observer using binoculars from a vehicle parked on a gravel road along the north edge of the plot. The time of observations, species, numbers, and activities (i.e., resting/perching/loafing, foraging, and dusting) of birds within plots were recorded.

\subsection{Data analyses}

Small mammal captures/recaptures and bird observations were treated descriptively. Capture/recapture, biological, or count data were presented as frequencies, means, or percentages, with captures and recaptures based on operable trap nights by crop type and trap session.

For damage analyses, numbers of sprouts, clipped plants, and disturbed-soil digs were dependent variables. Data were analyzed using mixed model, repeated measures analysis of variance (ANOVA; PROC MIXED; SAS Institute Inc., 1996). Measurements for corn were analyzed using two designs, an initial design involving three measurement periods $(2$ plot $\times 2$ protection $\times 3$ date) when exclosures were present and a subsequent design involving five measurement periods when exclosures were removed ( 2 plot $\times 5$ date). In the initial design, plot was considered a random effect, protection and date were considered fixed effects, and date was considered a repeated-measures factor (Winer, 1971). These analyses for clipped plants and disturbedsoil digs in corn yielded warnings of "infinite likelihood" (matrix convergence criteria not met). We were conservative with these data and elected not to transform nor report these results. The lack of convergence was attributed to the disparate, low incidence of counts for these variables (odd data structures). In the subsequent two-way ANOVAs, plot was a random effect and date a repeated-measures, fixed-effect factor (Winer, 1971). The soybean germination (sprout), clipped-plant, and soil-dig variables were analyzed as separate mixed model ANOVAs $(2$ plot $\times 2$ protection $\times 7$ date $)$, with plot a random effect, protection and date fixed effects, and date a repeated-measures factor (Winer, 1971). Exclosures remained in place throughout these soybean measurements. All treatment separations were evaluated using Tukey-Kramer or Adjusted Tukey post-hoc mean comparisons at the 0.05 level of significance (SAS Institute Inc., 1987, 1996).

\section{Results}

\subsection{Small mammal surveys}

Altogether, 63 capture and 39 recapture events comprised the small mammal data set (Tables 1 and 2). Species captured in descending order of frequency included: deer mouse, thirteen-lined ground squirrel, western harvest mouse, and northern grasshopper mouse. Deer mice accounted for $89 \%$ and $98 \%$ of all captures and recaptures, respectively; $61 \%$ were females. Based on operable trap nights, these data equated to captures and recaptures of $3.3 \%$ and $1.2 \%$ in July 2000 , $0.1 \%$ and $0.4 \%$ in September $2000,2.7 \%$ and $1.2 \%$ in April 2001, and $3.3 \%$ and $2.8 \%$ in July 2001, respectively.

Within crop types, the order of independent capture rates of animals (greatest to least) was: wheat $(25 \%)$, sunflower $(14 \%)$, millet $(9 \%)$, fallow $(8 \%)$, corn $(6 \%)$, and pea/wheat $(5 \%)$, and soybean $(5 \%)$ (Table 2$)$. In 2000, 11 deer mice were captured in wheat (Plot 1) adjacent to a small wooded area at the east end of the site. This area seemed to serve as a reservoir for the mice, and we observed mice run to the wooded area after release.

Captures were greatest (28\%) in the external (off-plot) trap grids, particularly those placed along the north edge of the site. This included all of the western harvest mice and northern grasshopper mice. Interestingly, this habitat was farmed as traditional, tilled Spring wheat rotated annually with fallow strips - the predominate cropping practice in the area and common habitat of the western harvest mouse. A large area of grassland was located about $1 \mathrm{~km}$ north of these grids; this coincided with common habitat of the northern grasshopper mouse.

\subsection{Bird observations}

Counts of birds were extremely low (Table 3). Five species of birds were observed in corn plots: horned lark, lark bunting, mountain plover, mourning dove, and western meadowlark; and, three species were observed in soybean plots: horned lark, killdeer plover, and lark bunting. Horned lark and lark bunting were the most prevalent species at the site. No observations of birds foraging on planted seeds or sprouts occurred.

Bird-activity observations for the corn plots yielded 34 activity observations involving mainly solitary birds of the species listed in Table 3; only four observations 
Table 1

Biological data for small mammal captures at a low-tillage, non-irrigated agriculture site in the Colorado Piedmont (2000-2001)

\begin{tabular}{|c|c|c|c|c|c|c|c|c|c|c|c|c|c|c|c|c|}
\hline \multirow[t]{3}{*}{ Species } & \multicolumn{8}{|c|}{2000} & \multicolumn{8}{|c|}{2001} \\
\hline & \multicolumn{4}{|c|}{ July } & \multicolumn{4}{|c|}{ September } & \multicolumn{4}{|c|}{ April $^{\mathrm{b}}$} & \multicolumn{4}{|c|}{ July } \\
\hline & $n$ & Sex & Wt. $(\bar{X} \pm \mathrm{SDg})$ & Age & $n$ & Sex & Wt. $(\bar{X} \pm \mathrm{SDg})$ & Age & $n$ & Sex & Wt. $(\bar{X} \pm \mathrm{SDg})$ & Age & $n$ & Sex & Wt. $(\bar{X} \pm \mathrm{SDg})$ & Age \\
\hline \multirow[t]{2}{*}{$\begin{array}{l}\text { Deer } \\
\text { Mouse }\end{array}$} & 22 & $10 \sigma^{\pi}$ & $28.8 \pm 2.9$ & $\begin{array}{l}5 \mathrm{~A} \\
2 \mathrm{SA} \\
3 \mathrm{~J}\end{array}$ & 1 & $1 \delta$ & 32.9 & $1 \mathrm{~A}$ & 11 & 30 & $18.9 \pm 3.7$ & $8 \mathrm{~A}$ & 22 & $8 \sigma$ & $26.3 \pm 10.8$ & $\begin{array}{l}5 \mathrm{~A} \\
3 \mathrm{SA}\end{array}$ \\
\hline & & 12 우 & $34.0 \pm 4.5$ & $\begin{array}{l}9 \mathrm{~A} \\
3 \mathrm{SA}\end{array}$ & & & & & & 89 & $22.1 \pm 5.9$ & $3 \mathrm{~A}$ & & 149 & $29.6 \pm 10.7$ & $\begin{array}{l}11 \mathrm{~A} \\
3 \mathrm{SA} \\
1 \mathrm{~J}\end{array}$ \\
\hline Thirteen-lined ground squirrel & 1 & 10 & 91.5 & $1 \mathrm{SA}$ & nd & nd & nd & nd & nd & nd & nd & nd & 2 & & & \\
\hline & & & & & & & & & & & & & & $2 ㅇ$ & $84.6 \pm 4.7$ & $2 \mathrm{~A}$ \\
\hline Western harvest mouse & $2^{\mathrm{c}}$ & 19 & $24.8 \pm 4.0$ & $2 \mathrm{~A}$ & nd & nd & nd & nd & nd & nd & nd & nd & 1 & 19 & 17.7 & $1 \mathrm{~A}$ \\
\hline Northern grass hopper mouse & 1 & 19 & 36.5 & $1 \mathrm{~A}$ & nd & nd & & nd & nd & nd & nd & nd & nd & nd & nd & nd \\
\hline
\end{tabular}

a Abbreviations: $n=$ number; $\delta \circ=$ gender; Wt. $=$ weight; Age $(\mathrm{A}=$ adult, $\mathrm{SA}=$ Sub-adult, $\mathrm{J}=\mathrm{Juvenile})$; nd $=$ no data.

${ }^{\mathrm{b}}$ Trapping session was half as long as the others due to snowfall.

${ }^{\mathrm{c}}$ One animal escaped before gender could be determined; weight and age were recorded.

Table 2

Specie x crop matrix of small mammal capture and recapture data during 2000-2001

\begin{tabular}{|c|c|c|c|c|c|c|c|c|c|c|c|c|c|c|c|c|}
\hline \multirow[t]{3}{*}{ Crop type } & \multicolumn{4}{|c|}{ Deer mouse } & \multicolumn{4}{|c|}{ Thirteen-lined ground squirrel } & \multicolumn{4}{|c|}{ Western harvest mouse } & \multicolumn{4}{|c|}{ Northern grashopper mouse } \\
\hline & \multicolumn{2}{|c|}{2000} & \multicolumn{2}{|c|}{2001} & \multicolumn{2}{|c|}{2000} & \multicolumn{2}{|c|}{2001} & \multicolumn{2}{|c|}{2000} & \multicolumn{2}{|c|}{2001} & \multicolumn{2}{|c|}{2000} & \multicolumn{2}{|c|}{2001} \\
\hline & $\mathbf{J}$ & $\mathrm{S}$ & A & $\mathbf{J}$ & $\mathrm{J}$ & $\mathrm{S}$ & A & $\mathbf{J}$ & $\mathrm{J}$ & $\mathrm{S}$ & A & $\mathbf{J}$ & $\mathrm{J}$ & $\mathrm{S}$ & A & $\mathbf{J}$ \\
\hline
\end{tabular}

Captures

Corn 4

Fallow $\quad 1 \quad 3 \quad 1$

Millet $\quad 2 \quad 4$

Peas 2

Soyabeans 2

$\begin{array}{llll}\text { Sunflowers } & 7 & 1 & 1\end{array}$

$\begin{array}{llll}\text { Wheat } & 11 & 1 & 3\end{array}$

$\begin{array}{lrlrr}\text { External } & 3 & 1 & 4 & 5\end{array}$

$\begin{array}{lllll}\Sigma & 22 & 1 & 11 & 22\end{array}$

Recaptures

$\begin{array}{lll}\text { Corn } & & 9 \\ \text { Fallow } & 1 & 1 \\ \text { Millet } & 1 & 1\end{array}$

Peas

Soyabeans

Sunflowers $3 \quad 1$

$\begin{array}{lllll}\text { Wheat } & 6 & 3 & 2 & 5\end{array}$

External $11 \quad 112$

$\begin{array}{lllll}\Sigma & 10 & 3 & 5 & 20\end{array}$

1

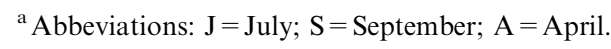

involved groups of several birds. Of these activity observations, $26(76 \%)$ were classified as resting/ perching/loafing and eight $(24 \%)$ were classed as foraging-insects or grit.

There were 52 specific bird-activity observations in soybean plots. Forty-one (79\%) observations involved solitary birds (Table 3), and 11 activity events involved groups of two to six birds. The specific breakdown of activities observed were: $41 \quad(79 \%)$ resting/perching/ loafing events, $10(19 \%)$ foraging on insects or grit events (i.e., not planted seed), and one ( $2 \%$ ) dusting event. 
Table 3

Bird observations $(0.5 \mathrm{~h} / \mathrm{day} / \mathrm{plot}$ on 4 plots) in corn and soybean plots (2001)

\begin{tabular}{|c|c|c|c|c|c|c|}
\hline Crop & Species & $\begin{array}{l}\text { May } \\
10\end{array}$ & $\begin{array}{l}\text { May } \\
15\end{array}$ & $\begin{array}{l}\text { May } \\
23\end{array}$ & $\begin{array}{l}\text { May } \\
25\end{array}$ & $\begin{array}{l}\text { May } \\
31\end{array}$ \\
\hline Corn & $\begin{array}{l}\text { Horned Lark } \\
\text { Lark Bunting } \\
\text { Mountain Plover } \\
\text { Mourning Dove } \\
\text { Western Meadow Lark }\end{array}$ & $\begin{array}{l}2 \\
1 \\
1\end{array}$ & $\begin{array}{l}6 \\
8 \\
2 \\
2\end{array}$ & $\begin{array}{l}8 \\
6\end{array}$ & & \\
\hline$\Sigma$ & & 4 & 18 & 17 & & \\
\hline Soybean & $\begin{array}{l}\text { Horned Lark } \\
\text { Lark Bunting } \\
\text { Killdeer Plover }\end{array}$ & & & & $\begin{array}{l}13 \\
19\end{array}$ & $\begin{array}{r}18 \\
1\end{array}$ \\
\hline$\Sigma$ & & & & & 32 & 19 \\
\hline
\end{tabular}

\subsection{Corn plant measurements}

Sprout data served to clarify possible seed removals and plant chronology. Initial germination of corn occurred $<14$ days after planting. The ANOVA for sprout data yielded only a date main effect $[F(2$, $111)=81.32, p \leqslant 0.01]$. Interpretation was straightforward; initial germination occurred mainly between May 15 and 23. Mean sprouts on the three successive measurement dates were: $0.42,0.42$, and 4.36. TukeyKramer verified that mean sprouts were greater on May 23 than on either May 10 or 15.

Following removal of exclosures, the two-way ANOVA for corn sprouts also yielded a date main effect $[F(4$, $152)=47.51, p \leqslant 0.01]$. Mean corn plants for the five dates were: June $6=4.05$, June $13=4.07$, June $20=4.25$, June $27=4.60$, and July $11=6.95$; the SE was 0.42 for all means. Thus, corn plants continued to germinate throughout the measurement periods.

\subsection{Soybean plant measurements}

Germination of soybeans occurred mainly $\leqslant 12$ days after planting (June 1-6; Fig. 2). The date main effect for sprouts was significant $[F(6,247)=440.01, p \leqslant 0.01]$, with mean sprouts on the seven successive measurement dates of $0.00,0.50,21.07,23.63,23.72,21.88$, and 22.62 $(\mathrm{SE}=0.57)$, respectively. Tukey-Kramer tests showed that means for the first two dates were less than for the last five dates.

Clipped soybean plants yielded a significant protection $\times$ date interaction $[F(6,247)=4.06, p \leqslant 0.01]$, as well as significant protection $[F(1,247)=15.20, p \leqslant 0.01]$ and date $[F(6,247)=4.06, p \leqslant 0.01]$ main effects. Mean clipped soybean plants increased in unprotected (nonexclosure) row segments during the June 13-27 measurements (Fig. 3); whereas, no plants were clipped within exclosures. Mean damage to unprotected plants

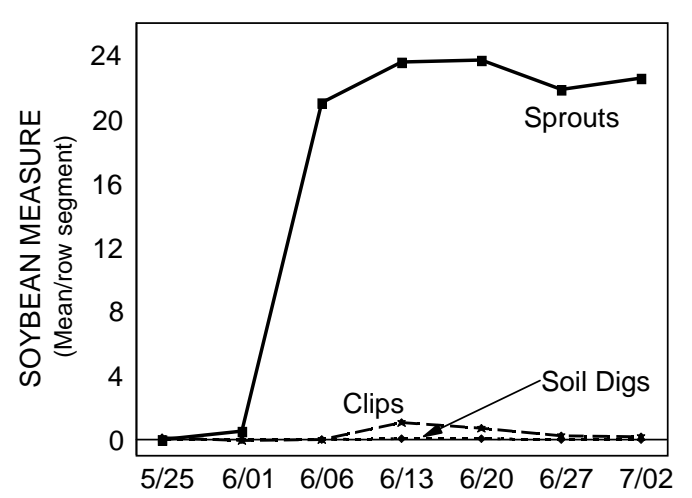

Fig. 2. Mean soybean sprouts, plant clips, and small mammal soil digs across measurement dates - chronology of germination and damage.

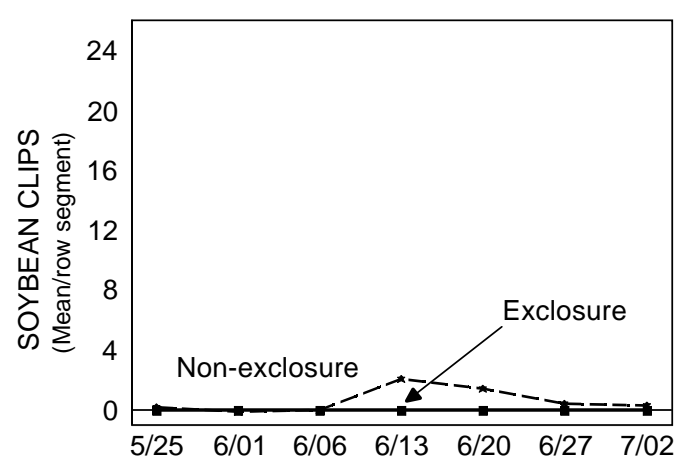

Fig. 3. Protection $\times$ date interaction for mean plant clips in soybeans.

were $0.15,0.00,0.00,2.05,1.40,0.40$, and 0.30 for respective measurements, with $\mathrm{SE}=0.31$. Post-hoc tests confirmed that clipping damage for the 4th (June 13) and 5th (June 20) counts of unprotected plants were significantly greater than other non-exclosure and exclosure means. 
Regarding the main effects, the mean number of soybean plants clipped across dates were 0.08, 0.00, 0.00 . 1.02, 0.70, 0.20, and 0.15; while mean exclosure versus non-exclosure soybean plants showing damage were 0.60 and 0.00 , respectively. This essentially substantiated the previous interaction. Tukey-Kramer tests showed that the June 13 and 20 means were higher than those of other dates, and of course, the exclosures effectively stopped damage. The non-transitive increases in clipped plants for successive measurement dates is viewed to reflect the effects of new plant growth upon detection of clipped-plant damage; foliage became blackened (dead), then shriveled and dropped off after about one week. New soybean growth made identification of previous clips difficult to detect in about 2 weeks.

The number of small mammal soil digs yielded a significant protection $\times$ date interaction $[F(6,266)=$ $2.46, p \leqslant 0.03$ ], with no other effects significant. Both exclosure (protected) and non-exclosure (unprotected) row segments had mean 0.1 soil digs/152-cm row length on June 20 and June 13, respectively, with all other dates void of digs. Thus, while attempts by animals to scratch or dig soil was not unique to exclosure or non-exclosure row segments, these disturbances were transitory, occurring mainly during specific measurement sessions in protected and unprotected sampling areas.

\subsection{Other crop damage observations}

During the September 2000 trap session, we noted considerable "large-animal" damage to corn and soybean crops. Corn damage was attributed to racoons (Procyon lotor) and deer; tracks of these animals were present in plots and partially bitten ears were found on the ground. Soybean damage was attributed to deer and jack rabbits; these animals were visually sighted in plots, and plucked and nipped foliage marks were noted on some plants. Although enumeration of damage to soybean plants was not conducted, full enumeration of corn damage in 2 plots showed that corn ear loss was clustered along interior rows and equaled 0.638 damaged plants $/ \mathrm{m}^{2}$ (Engeman and Sterner, 2002). This type of damage did not occur in 2001-a year of near average precipitation.

\section{Discussion}

It is doubtful that small mammals or birds pose serious risks to crop damage in low-tillage, non-irrigated schemes of the Colorado Piedmont. Diverse aspects of our results support this statement. There were no direct observations of corn or soybean seed/sprout removal by animals or birds. Few small mammals were caught, and few birds were observed utilizing crops. There were minimal signs of squirrel or avian activity (scratches/soil disturbances) associated with sampling areas of planted seeds/sprouts. Additionally, the theoretical mean corn plants per row segment was 6.69 sprouts $(152-\mathrm{cm}$ length $\div 26.7 \mathrm{~cm}$ seed spacing), and mean corn sprouts in our plots on July 11 were 8.1 and 5.8 , respectivelyvalues within $1 \mathrm{SD}$ of the expected mean.

Numbers, body weights, and sizes of animals captured reflected both seasonal reproduction phenology and drought onset. Highest captures characterized the July data in both years, with extremely low captures for April and September. This pattern reflects the typical annual reproduction pattern of rodents, especially the prevalent deer mouse at this site, but it is exaggerated in our results due to the low total captures. Not only did the fewest captures and recaptures occur during the September 2000 trap session (an initial drought period), but this datum consisted of a single adult male deer mouse in nonbreeding condition. The capture and recapture data for 2001 then showed the resilience of these small mammal populations, particularly Peromyscus, with a return to pre-drought capture and recapture frequencies. No subadult or juvenile animals were captured during the September 2000 or April 2001 trap sessions.

Prior reports have linked prairie voles (Hines, 1993,1997) and deer mice (Hyngstrom et al., 1996) with damage to emerging corn and soybeans in "no-till" cropping schemes. Interestingly, the deer mouse was the most prevalent species captured in both our study and that of Hyngstrom et al. (1996). Nevertheless, all of the earlier reports refer to the central or eastern Great Plains, and describe the accumulation of surface plant residue (debris) from previous cropping cycles as characteristic of potential damage situations. We contend that the sporadic periods of high winds in eastern Colorado, coupled with the relatively low precipitation/ humidity, retard vegetative debris accumulation and afford little cover for small mammal populations in lowtill, dryland agriculture - a key difference between cropping in the Colorado Piedmont and the rest of The Great Plains.

Our low capture-recapture rates of small mammals $(2.2 \%)$ concur with prior trapping efforts for eastern Colorado (McEwen et al., Unpublished data; Moulton et al., 1981a, b); still, the capture of only four species was unexpectedly limited and unique. McEwen et al. (Unpublished data) captured 1457 animals of 11 species (2$10 \%$ nightly) at the Central Plains Experimental Range (CPER) within the western end of the Pawnee National Grasslands (see Fig. 1). The three most frequently captured species at that "agriculturally disturbed short-grass prairie" site were: thirteen-lined ground squirrel $(35.5 \%)$, deer mouse $(25.6 \%)$, and northern grasshopper mouse $(17.8 \%)$. Moulton et al. (1981a) caught 144 animals and 11 species during a total of 3160 trap nights ( $4.6 \%$ capture success) at Yuma, Vilas, and 
Campo County sites (High Plains), with northern grasshopper mouse $(33 \%)$ the most frequent captured (i.e., the deer mouse accounted for $11 \%$ of trapped animals). Importantly, vegetative cover at these locations was characterized as $39-54 \%$ bare ground with 26-47\% debris. Moulton et al. (1981b) trapped 314 animals of 13 species ( $2.3 \%$ captures) in a total of 13,840 trap nights (unadjusted for failed operation) at six locations in Yuma County (High Plains), with the western harvest mouse $(40 \%)$ and deer mouse $(23 \%)$ the most common; grazed and ungrazed riparian habitats were linked with the most frequent captures of these (or any) animals. While sign of thirteen-lined ground squirrels was prevalent during our survey, closing traps during daylight hours probably accounted for the few captures of this and other diurnal species.

Species-distribution maps for small mammals in Colorado show that 15 species have ranges overlapping our research site (see Fitzgerald et al. 1994): deer mouse, thirteen-lined ground squirrel, western harvest mouse, northern grasshopper mouse, hispid pocket mouse (Chaetodipus hispidus), house mouse (Mus musculus), meadow vole (Microtus pennsylvanicus), Norway rat (Rattus norvegicus), olive-backed pocket mouse (Perognathus fasciatus), Ord's kangaroo rat (Dipodomys ordii), plains harvest mouse (Reith. montanus), plains pocket mouse (Perognathus flavescens), prairie vole (M. ochrogaster), silky pocket mouse (Perog. flavus), and spotted ground squirrel ( $S$. spilosoma). The fact that we caught only about one-fourth of these species is perhaps best explained by our somewhat limited trap nights (2796) and our setting of traps mainly in cropped plots away from riparian, wooded, and other habitats.

As stated, 2000 initiated a drought period in eastern Colorado (Fig. 4). Average annual moisture for the Site is $34.7 \mathrm{~cm}$ (Peterson et al. 2000); actual precipitation for 2000 totaled $19.1 \mathrm{~cm}$ (i.e., $55 \%$ of annual mean precipitation), with the July and September (trap sessions) precipitation equal to 1.29 and $2.31 \mathrm{~cm}$, respectively. Precipitation in 2001 provided a temporary "break" from the start of this drought, with $32.7 \mathrm{~cm}$ (94\% of average) annual precipitation recorded; however, 2002 has yielded extreme drought conditions again, with total precipitation for the January-July period of $8.2 \mathrm{~cm}$ ( $\approx 30 \%$ of average for these months). Obviously, small mammals, in particular Peromyscus maniculatus, were stressed by these conditions as evidenced by our extremely poor September 2000 capture/recapture data. Still, animal captures rebounded rapidly in 2001, with the quick vegetation growth linked to $20 \mathrm{~cm}$ of moisture during April-June (i.e., roughly the months preceding our trap sessions). That populations migrated to farmsteads or shortgrass prairie and returned rapidly to plots upon recurrence of typical precipitation is suggested by the fact that our April 2001 captures were largely adult, not sub-adult and juvenile mice.

\section{Conclusions and implications}

Risks of rodent and avian damage to low-tillage, dryland crops in the Colorado Piedmont appear to be

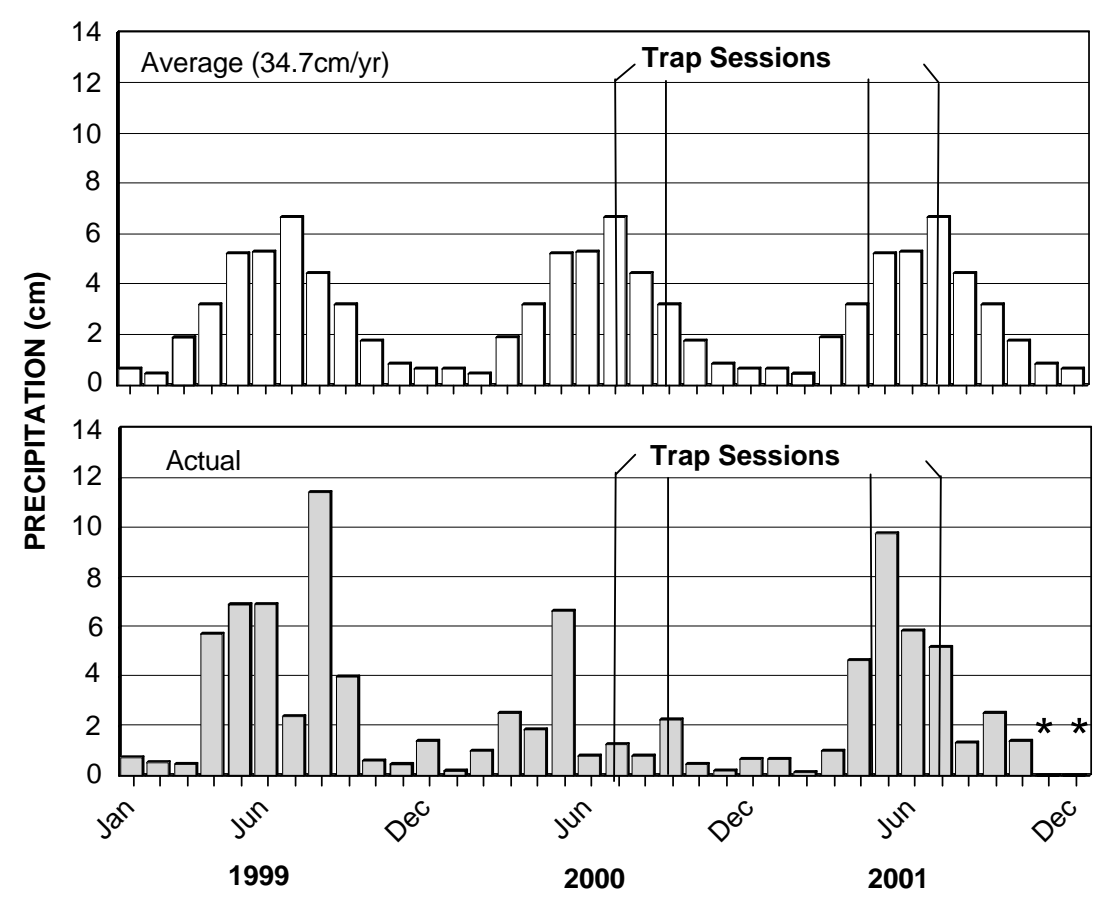

Fig. 4. Average (1961-1990) monthly precipitation (top) and actual monthly precipitation (1999-2001) for the site. [* Precipitation measurements lacking between November 25-December 10 inclusive due to equipment failure; precipitation during this period was essentially nil]. 
minor. The main, annually alternated, wheat-fallow, tilled cropping scheme practiced here favors the natural history of the deer mouse - a wide-ranging rodent that prefers "disturbed" habitat (Fitzgerald et al., 1994; Stickel, 1968). This rodent inhabits all but wetland ecosystems in Colorado. Females have multiple litters of about five young (2-8) annually, with some data suggesting that these mice become pregnant year round in the Piedmont (Fitzgerald et al., 1994). Even low-tillage practices disturb soil and shift debris; this displaces other rodents and is a key attraction for the deer mouse. Although the horned lark has been linked with seed removal and sprout damage to agriculture in many locales, most reports involve cultivated, irrigated crops in other regions of the US (York et al., 2000); densities are too low here. Greater threats are likely posed by deer, jack rabbits, and raccoons, especially during droughts and at harvest.

Surface plant debris warrants manipulation as a factor affecting small mammal damage in low-till agriculture. While we recognize that the lack of accumulated plant residue at our site was confounded with the short period of low-tillage, dryland cropping ( $<3$ years), debris accumulation and depth could account for the major differences in small mammal abundance and crop damage between our study and other reports of wildlife damage to "no-till" agriculture in more humid, less windswept areas of The Great Plains (Hines, 1993, 1997; Hyngstrom et al., 1996). At our site, the build up of even a thin layer of debris from prior crop cycles was limited to stalk-type crops (corn, sunflower). The high winds and minimal relief evident at our study site, coupled with greater debris accumulation at other dryland sites on the High Plains (Poss, 2001), suggest that this factor may explain significant variance in small mammal abundance and crop damage in diverse low-tillage agroecosystems.

\section{Acknowledgements}

We thank Drs. Gary Peterson and Frank Peairs, Dryland Agroecosystem Project, Colorado State University, for cooperation. Drs. Craig Ramey and Kathy Fagerstone provided helpful comments on the draft manuscript. An anonymous reviewer also provided constructive criticism.

\section{References}

Bauer, A., Black, A.L., 1981. Soil, carbon, nitrogen, and bulk density comparisons in two crop land tillage systems after 25 years and in virgin grassland. Soil Sci. Soc. Amer. J. 45, 1166-1170.
Bowman, R.A., Reeder, J.D., Lober, R.W., 1990. Changes in soil properties in a central plains rangeland soil after 3, 20, and 60 years cultivation. Soil Sci. 150, 851-857.

Dhuyvetter, K.C., Thompson, C.R., Norwood, C.A., Halvorson, A.D., 1996. Economics of dryland cropping systems in the great plains: a review. J. Prod. Agric. 9 (2), 216-222.

Engeman, R.M., Sterner, R.T., 2002. A comparison of potential laborsaving sampling methods for assessing large mammal damage in corn. Crop Prot. 21, 101-105.

Fitzgerald, J.P., Meany, C.A., Armstrong, D.M., 1994. Mammals of Colorado. University Press of Colorado, Niwot, CO, 467pp.

Hammerson, G.A., 1999. Amphibians and Reptiles in Colorado. University Press of Colorado, Niwot, CO, pp. 9-38.

Hines, R.A., 1993. Prairie vole damage control in no-till corn and soybean. Proc. Great Plains Wildl. Dam. Wkshp. 11, 134-140.

Hines, R.A., 1997. Rodent damage control in no-till corn and soybean production. Proc. Eastern Wildl. Dam. Mgmt. Conf. 7, $195-199$.

Hyngstrom, S.E., Vercauteren, K.C., Ekstein, J.D., 1996. Impacts of field-dwelling rodents on emerging field corn. Proc. Vert. Pest Conf. 17, 148-150.

Krall, J.M., Shulman, G.E., 1996. Integrated dryland crop and livestock production systems on the great plains: extent and outlook. J. Prod. Agric. 9 (2), 186-191.

Moulton, M.P., Choate, J.R., Bissell, S.J., Nicholson, R.A., 1981a. Associations of small mammals on the central high plains of eastern colorado. Southwest. Nat. 26, 53-57.

Moulton, M.P., Choate, J.R., Bissell, S.J., 1981b. Small mammals on revegetated agricultural land in eastern Colorado. Prairie Nat. 13, 99-104.

Peterson, G.A., Schlegel, A.J., Tanaka, D.L., Jones, O.R., 1996. Precipitation use efficiency as affected by cropping and tillage systems. J Prod. Agric. 9 (2), 180-186.

Peterson, G.A., Westfall, D.G., Peairs, F.B., Sherrod, L., Poss, D., Gangloff, W., Larson, K., Thompson, D.L., Ahuja, L.R., Koch, M.D., Walker, C.B., 2000. Sustainable dryland agroecosystem management. Technical Bulletin (TB00-3), Colorado Agricultural Experiment Station, Departments of Soil and Crop Sciences and Bioagricultural Sciences and Pest Management, Colorado State University, Fort Collins, CO, 83pp.

Poss, D.J., 2001. Insects \& dryland cropping systems-Briggsdale: 2000 annual report. Department of Bioagricultural Sciences and Pest Management, Colorado State University, Fort Collins, CO, 22pp.

SAS Institute Inc. 1987. SAS/STAT Guide for Personal Computers. SAS Institute, Inc. Cary, NC, pp. 549-560.

SAS Institute Inc. 1996. The MIXED Procedure. SAS/STAT Software: Changes and enhancements. Release 6.11. Cary, NC, pp. 533-656.

Stickel, L.F., 1968. Home range and travels (of Peromyscus). In: King, J.A. (Ed.), Biology of Peromyscus (Rodentia). Special Publication 2, American Society of Mammalogists, Lawrence, KS, USA, pp. 373-411.

Winer, B. J. 1971. Statistical Principles in Experimental Design. McGraw-Hill, New York, pp. 149-305, 559-571.

York, D.L., Cummings, J.L., Engeman, R.E., Davis Jr., J.E., 2000. Evaluation of flight control ${ }^{\mathrm{TM}}$ and mesurol $\mathbb{R}$ as repellents to reduce horned lark (Eremophila alpestris) damage to lettuce seedlings. Crop Prot. 19, 201-203. 